\title{
Cartas para ensinar a aprender
}

Por Ricardo Prado, editor da Revista Veras

O educador português José Pacheco tornou-se conhecido no Brasil graças a um livro de Rubem Alves que revelou o processo de transformação radical de uma escola pública localizada no distrito de Porto, a Escola da Ponte. No livro A Escola com que sempre sonhei sem imaginar que pudesse existir (2005), o educador campineiro se encantava com a liberdade proposta por Pacheco aos estudantes da escola que escolheu revolucionar. Depois de enfrentar resistências internas e externas, a experiência da Escola da Ponte tornou-se reconhecida em Portugal e em outros países - por aqui, principalmente graças ao citado livro de Alves, que rendeu ao educador português os primeiros convites para palestras em solo brasileiro. De curiosa experiência radical de escola democrática, a Escola da Ponte se tornaria um ícone da renovação pedagógica, uma espécie de Summerhill renovada.

A recepção às ideias de Pacheco em nosso país foi tão calorosa que ele acabou ficando entre nós após se aposentar. E mergulhou nos dilemas e impasses da educação brasileira. Aprender em Comunidade, livro lançado em 2014 pela Edições SM, é fruto dessa imersão e traz uma proposta estimulante e inovadora. Escrito em forma de cartas endereçadas a educadores e brasileiros ilustres já mortos, o livro tem um duplo mérito em seu formato original: remete o leitor ao ideário buscado continuamente pelo educador, qual seja, a difícil e necessária arte de formar comunidades dinâmicas de aprendizagem, capazes de se autoalimentarem a partir da identificação de demandas coletivas, ao mesmo tempo em que dá conta de reavivar alguns conceitos e ideias caras ao educador a quem a carta é endereçada. Para isso, uma sintética biografia e alguns sites para pesquisa mais aprofundada do leitor encerram cada missiva. Em todos os escolhidos, permanece o objetivo: garimpar aspectos dos trabalhos desses educadores que criem oportunidades de diálogo com qualquer professor contemporâneo interessado em criar entre seus alunos uma comunidade aprendiz. 
A lista de pensadores é densa e expressiva. Vai de nomes consagrados na Educação, como Anísio Teixeira, Paulo Freire, Darcy Ribeiro, Lauro de Oliveira Lima, Fernando de Azevedo, Nise da Silveira, Milton Santos, Padre Vieira e Rui Barbosa, a outros educadores menos estrelados, mas que em algum momento se interessaram pelo tema geral da obra, o aprender em comunidade. Assim, temos a oportunidade de conhecer um pouco sobre mestres dedicados à educação de qualidade que não tiveram o devido reconhecimento público, como Eurípedes Barsanulfo, mais conhecido apenas entre os habitantes da mineira Sacramento, Maria Nilde Mascellani, ativa militante paulistana da educação popular, ou Helena Antipoff, bielorrussa que adotou o Brasil como pátria e a educação inclusiva de crianças com necessidades especiais como tema de seu fecundo trabalho em Minas Gerais. Até mesmo Antônio Conselheiro, o ultrarreligioso líder da Revolta de Canudos, por ter conseguido criar às margens do rio Vaza-Barris uma comunidade de aprendizagem, merece uma atenciosa carta de Pacheco.

Cada carta é reveladora de alguma faceta pela qual as escolas brasileiras parecem condenadas à "perpetuação de uma gestão centralizada no sistema, impedindo que assumam a dignidade da autonomia e se constituam em elementos orgânicos de comunidades de aprendizagem". A boa notícia é que o próprio autor enfrentou, e com sucesso, essa mesma resistência inercial às mudanças. Pode ser que as cartas enfeixadas nessa edição contenham o germe capaz de transformar o "desenquistamento isolacionista da escola tradicional", nos dizeres de Lauro Oliveira Lima, para quem, no futuro, toda escola deveria se tornar um centro comunitário, sem se reduzir a "um lugar fixo murado". Contra os muros e a favor das escolas que saem de seu isolamento e se descobrem como centros de aprendizagem coletiva, as cartas de José Pacheco formam um energético aluvião de ideias e propostas renovadoras.

\section{REFERÊNCIAS}

ALVES, Rubem. A Escola com que sempre sonhei sem imaginar que pudesse existir. Campinas: Papirus, 2005.

PACHECO, José. Aprender em comunidade. São Paulo: Edições SM, 2014, 132 p. 